\title{
EFEKTIVITAS EDUKASI VIDEO UNTUK KELENGKAPAN PENJELASAN CARA PENGGUNAAN INHALER OLEH MAHASISWA APOTEKER
}

\author{
Submitted : 27 Maret 2020 \\ Edited : 22 Desember 2020 \\ Accepted : 29 Desember 2020 \\ Amelia Lorensia $^{1}$, Rifaatul Laila Mahmudah ${ }^{2}$, Ema Arifatul Masruroh ${ }^{1}$, Navaul Setiya \\ Ningrum ${ }^{1}$ \\ ${ }^{1}$ Departement of Community and Clinical Pharmacy, Pharmacy Faculty, University of \\ Surabaya, Jl. Raya Kalirungkut, Surabaya, Jawa Timur 60293 Indonesia \\ ${ }^{2}$ Departement of Public Health, Stikes Majapahit, Jl. Raya Gayaman No.Km. 02, Mojokerto, \\ Jawa Timur 61364 Indonesia \\ Email : amelia.lorensia@gmail.com; amelia.lorensia@staff.ubaya.ac.id
}

\begin{abstract}
Pharmacists are one of the health workers who play a role in providing information related to explanations of how to use inhaler preparations to asthma patients. This study aims to determine the effectiveness of providing educational videos on how to use several types of inhalers (MDI, MDI with spacers, Diskus ${ }^{\circledR}$, and Bodyaler ${ }^{\circledR}$ given to pharmacist students. This research is a pre-post design (experimental) study. Sampling was conducted using the method non random sampling using purposive technique, normality test using Shapiro-Wilk and continued.From the results of the data obtained, each assessment verbally (as explained by the subject) and motoric assessment (as demonstrated by the subject) is seen from the pre-and post-intervention Comparing the completeness of explanations both verbally and motorically, showing significant differences compared to before education, with $P$ values for $\operatorname{MDI}(P(0,000)$ $\unlhd 0.05), M D I$ with spacers $(P(0,000) \quad 0.05)$ Diskus ${ }^{\circledR}(P(0,000) \quad \$ 0.05)$, and Turbuhaler ${ }^{\circledR}(P$ $(0,000), 00.05)$, therefore video education has proven to be effective in increasing student proficiency. self-pharmacist to explain how to use inhalers.
\end{abstract}

Keywords: inhaler technique, asthma, pharmacist students, educational videos

\section{PENDAHULUAN}

Asma merupakan penyakit heterogen yang ditandai peradangan kronis pada saluran nafas, berupa munculnya gejala mengi, sesak nafas, dan batuk (1). Berdasarkan hasil Riset Kesehatan Dasar (RISKESDAS) tahun $2018^{(2)}$, menyatakan jumlah proporsi kekambuhan asma di Indonesia dalam 12 bulan terakhir sebesar $57,5 \%$ dan di provinsi Jawa Timur sebesar $58 \%$. Pencapaian kontrol gejala yang baik dan minimalnya resiko serangan asma merupakan tujuan jangka panjang dari pengobatan asma. Serangan asma ditandai dengan penurunan arus nafas dan dapat mengakibatkan kematian. Asma tidak dapat disembuhkan, namun gejala dan perburukannya dapat dikontrol sehingga tidak mengganggu aktivitas sehari-hari. Salah satu upaya untuk menjaga supaya gejala asma tetap terkontrol yaitu diperlukan pengobatan optimal dengan cara penggunaan obat yang benar ${ }^{(1)}$, dengan menggunakan obat sesuai langkah-langkah yang tepat tanpa melakukan kesalahan kritis sehingga pengobatan menjadi efektif ${ }^{(3)}$. 
Bentuk sediaan untuk terapi asma paling ideal adalah melalui rute inhalasi yaitu dengan alat yang disebut inhaler. Keuntungan pada terapi inhalasi yaitu obat dihantarkan langsung ke dalam saluran pernapasan dan langsung masuk ke dalam paru-paru, kemudian menghasilkan konsentrasi lokal yang lebih tinggi dan memiliki risiko efek samping sistemik yang lebih rendah. Pada rute inhalasi obat tidak mengalami metabolisme lintas pertama sehingga memiliki onset brokodilator yang cepat ${ }^{(\mathbf{1}, \mathbf{4})}$. Pemilihan perangkat inhaler yang tepat bisa menjadi langkah awal menuju pengobatan optimal. Oleh karena itu, pertimbangan yang cermat harus diberikan dalam memilih perangkat inhaler karena perangkat yang berbeda memiliki teknik penggunaan yang berbeda ${ }^{(4,6,7)}$. Terapi inhalasi pada pasien asma dapat diberikan menggunakan nebulizer, Dry Powder Inhaler (DPI), dan Metered Dose Inhaler $(\mathrm{MDI}){ }^{(4,8)}$.

MDI merupakan alat inhaler yang sudah lama digunakan, tetapi sering kali menimbulkan masalah karena kurang koordinasi antara penekanan canister dengan inspirasi napas, sehingga banyak obat yang terdeposit di dalam mulut dan dapat menyebabkan candidiasis orofaringeal (1,9,10). Penelitian yang dilakukan oleh Al-Jahdali et al. (2013) (11) pada 203 pasien asma, menunjukkan bahwa sebanyak 189 pasien (93\%) menggunakan MDI dengan tidak tepat. Sedangkan penelitian lain yang dilakukan oleh Arora et al. (2014) ${ }^{(12)}$ pada 300 pasien, menunjukkan 94\% melakukan kesalahan dalam menggunakan MDI. Dampak yang terjadi dari kesalahan koordinasi dalam penggunaan MDI yaitu dapat menyebabkan obat yang sampai di paru-paru menjadi tidak optimal sehingga mengakibatkan kegagalan terapi pada pasien yang kemudian menyebabkan produktivitas menjadi rendah dan biaya perawatan kesehatan menjadi lebih mahal
(13,14). Sehingga mulai ada sediaan inhaler baru yang bisa menggantikan kelemahan dari MDI yaitu DPI. Walaupun penggunaan DPI masih belum sebanyak MDI karena harganya yang relatif lebih mahal dan memiliki keterbatasan dalam laju kecepatan obat ke target organ karena masih tergantung kekuatan inspirasi pasien sendiri $(4,15)$.

Pengobatan asma merupakan pengobatan jangka panjang yang harus tetap dikontrol penggunaannya oleh apoteker (16,17). Penelitian terdahulu oleh Osman et al. (2012) ${ }^{(18)}$ tentang pengukuran kemampuan farmasis terhadap teknik penggunaan inhaler menunjukkan kemampuan apoteker yang kurang dalam menjelaskan cara penggunaan inhaler. Di Surabaya sendiri penelitian serupa juga dilakukan terhadap apoteker dalam menjelaskan alat inhaler jenis DPI ${ }^{(19,20)}$, MDI ${ }^{(21)}$, dan MDI dengan spacer ${ }^{(22)}$, dan semua hasil penelitian tersebut tidak ada apoteker yang dapat menjelaskan alat inhaler tersebut secara optimal.

Edukasi kepada apoteker dalam meningkatkan pengetahuan farmasis mengenai cara penggunaan inhaler di kota Surabaya telah dilakukan oleh Lorensia et al. (2017) ${ }^{(23)}$, namun diketahui bahwa apoteker memiliki motivasi yang rendah dan hanya 2,9\% saja apoteker yang bersedia sedangkan sebagian besar alasan apoteker tidak bersedia karena kesibukan pekerjaan masing-masing dan kesulitan untuk mengatur jadwal bertemu. Oleh arena itu, pada penelitian ini edukasi diberikan kepada calon apoteker yaitu mahasiswa program studi apoteker, seperti yang dilakukan oleh Basheti et al. (2015) (24) yang meneliti efektifitas modul pendidikan standar pada mahasiswa farmasi tentang keterampilan teknik demonstrasi inhaler, dan menunjukkan bahwa sebagian besar mahasiswa (78\%) meyakini bahwa kurangnya praktek menggunakan alat inhaler adalah penghalang utama untuk 
memperbaiki penggunaan inhaler. Hal ini untuk menunjang kompetensi lulusan apoteker dalam melaksanakan salah satu perannya menurut PERMENKES RI No.73 tahun $2016{ }^{(25)}$, yaitu apoteker harus memberikan konseling mengenai sediaan farmasi dalam menunjang pengobatan sehingga memperbaiki kualitas hidup pasien, terhindar dari bahaya penyalahgunaan atau penggunaan obat yang salah.

Penelitian ini menggunakan media video karena terdapat unsur audio dan visual, yang melibatkan pendengaran dan penglihatan sekaligus dalam satu proses atau kegiatan. Pesan dan informasi yang dapat disalurkan melalui media ini dapat berupa pesan verbal dan nonverbal yang mengandalkan penglihatan maupun pendengaran. Keunggulan edukasi menggunakan video yaitu lebih cepat dan lebih efektif dalam menyampaikan pesan dibandingkan media teks dan mampu menunjukkan secara jelas prosedur dari suatu langkah-langkah ${ }^{(26,27)}$. Audio berisi petujuk penjelasan penggunaan alat inhaler yang benar dan visual berisi langkahlangkah gerakan penggunaan alat inhaler yang benar. Penelitian ini bertujuan untuk mengetahui efektivitas edukasi video untuk kelengkapan penjelasan cara penggunaan inhaler oleh mahasiswa apoteker.

\section{METODE PENELITIAN}

Penelitian ini dikategorikan sebagai jenis eksperimental dengan pre-post design. Variabel pada penelitian ini adalah edukasi video mengenai cara penggunaan inhaler yang terdiri dari MDI, MDI dengan spacer, Diskus ${ }^{\circledR}$, dan Turbuhaler ${ }^{\circledR}$ (variabel bebas) dan kelengkapan penjelasan cara pengguan inhaler tersebut (variabel tergantung). Penelitian dilaksanakan pada bulan Februari sampai dengan bulan Juni 2019.

Edukasi yang diberikan kepada sampel (subjek) penelitian berupa edukasi dalam bentuk video. Edukasi dalam bentuk video tersebut berisi penjelasan langkahlangkah cara penggunaan inhaler ${ }^{(4,17)}$. Penilaian kelengkapan cara penggunaan inhaler dibagi menjadi 2, yaitu penilaian secara verbal (penjelasan secara lisan) dan penilaian secara motorik (penjelasan dengan memperagakan).

Populasi terjangkau pada penelitian ini adalah mahasiswa profesi apoteker, baik pada saat pendidikan Strata-1 maupun profesi apoteker, keduanya harus ditempuh di satu universitas yang sama di daerah Surabaya Selatan. Subjek dalam penelitian ini bagian dari populasi yang bersedia terlibat dalam penelitian dan tidak pernah menggunakan inhaler untuk pengobatan dirinya sendiri. Jumlah subjek penelitian dapat dihitung menggunakan rumus binomunal proportions karena jumlah populasi penelitian diketahui, dengan perhitungan:

$$
n=\frac{Z^{2}{ }_{1} \alpha_{2} p(1-p) N}{d^{2}(N-1)+Z^{2}{ }_{1} \alpha_{2} p(1-p)}
$$

Keterangan:

$$
\begin{array}{ll}
\mathrm{Z} 21-\alpha / 2 & =1,962 \\
\mathrm{p} & =\text { jumlah sampel yang }
\end{array}
$$
diberikan intervensi yaitu sebanyak 45 orang 1-p = jumlah sampel yang tidak diberikan intervensi yaitu sebanyak 45 orang $\mathrm{N} \quad=$ besar populasi yaitu mahasiswa profesi apoteker yaitu sebanyak 402 orang

$\mathrm{d} \quad=$ derajat ketepatan yang diinginkan yaitu 0,05

Dari hasil perhitungan rumus diatas maka diketahui jumlah subjek minimal pada penelitian ini adalah sebanyak 114 mahasiswa profesi apoteker di Fakultas Farmasi Universitas Surabaya.

Instrumen yang digunakan pada penelitian ini terdiri atas lima macam yaitu inhaler (MDI, spacer, Diskus ${ }^{\circledR}$ dan Turbuhaler() sebagai alat peraga, media visual berupa video yang berisi materi 
edukasi, serta lembar checklist. Video disusun berdasarkan langkah-langkah yang terdapat dalam lembar checklist yang nantinya akan digunakan sebagai lembar penilaian. Dalam lembar checklist tersebut. Video yang digunakan dalam penelitian:
a. Video edukasi MDI (https://youtu.be/lu51vkkRWos)
b. Video edukasi MDI dengan spacer (https://youtu.be/MnVilAz8IeE)
c. Video edukasi Diskus ${ }^{\circledR}$ (https://youtu.be/Cq-OLAKgyF4)
d. Video edukasi Turbuhaler® (https://youtu.be/7afjC9azyvQ)

\section{Tahapan Cara Penggunaan MDI ${ }^{(4,18)}$ :}

1. Buka dan lepaskan penutup pada mouthpiece MDI (ujung inhaler)

2. Kocok inhaler segera setiap kali sebelum digunakan (posisi inhaler inhaler tegak, kocok pelan keatas dan kebawah)

3. Buang napas penuh melalui mulut

4. Pegang inhaler dengan posisi mouthpiece di bawah (posisi inhaler tegak)

5. Duduk tegak \& bernafas normal

6. Tekan bagian tabung atas (canister), bersama dengan itu hirup secara perlahan \& mendalam melalui mulut

7. Tahan napas selama maksimal 10 detik

8. Kumur mulut dengan air dan buang (jangan ditelan)

Tahapan Cara Penggunaan MDI dengan Spacer $^{(4,18)}$ :

1. Buka dan lepaskan penutup pada mouthpiece MDI (ujung inhaler)

2. Kocok inhaler segera setiap kali sebelum digunakan (posisi inhaler inhaler tegak, kocok pelan keatas dan kebawah

3. Buang napas penuh melalui mulut

4. Pegang inhaler dengan posisi mouthpiece di bawah (posisi inhaler tegak)

5. Pasang spacer pada inhaler
6. Tempatkan corong spacer

7. Duduk tegak $\&$ bernafas normal

8. Tekan bagian tabung atas (canister), bersama dengan itu hirup secara perlahan \& mendalam melalui mulut

9. Tahan napas selama 10 detik, kemudian hembuskan secara perlahan melalui mulut

10. Lepas spacer \& tutup kembali bagian ujung inhaler (mouthpiece)

11. Kumur mulut dengan air dan buang (jangan ditelan)

Tahapan Cara Penggunaan Diskus ${ }^{\circledR}{ }^{(4,18)}$ :

1. Tempatkan ibu jari pada thumbgrip dan geser ke kanan sampai bunyi klik

2. Tempatkan ibu jari pada tuas dan geser ke kanan sampai bunyi klik

3. Memegang Diskus ${ }^{\circledR}$ dengan posisi horizontal

4. Tariklah nafas dan hembuskan jauh dari mouthpiece Diskus ${ }^{\circledR}$

5. Tempatkan Diskus ${ }^{\circledR}$ di mulut antara gigi dan bibir dengan benar

6. Tarik nafas secara mendalam melalui mulut

7. Lepaskan mouthpiece Diskus ${ }^{\circledR}$ dari mulut dan tahan nafas yang dalam selama 5-10 detik

8. Hembuskan dan bernapas perlahanlahan

9. Tempatkan ibu jari pada thumbgrip dan geser kembali ke arah kiri sampai terdengar bunyi klik

Tahapan Cara Penggunaan Turbuhaler ${ }^{\circledR}$ (4,18):

1. Buka dan lepaskan penutup Turbuhaler®

2. Tegakkan Turbuhaler®

3. Putar grip ke arah berlawanan sampai terdengar bunyi klik

4. Buang napas penuh melalui mulut

5. Pada saat menghembuskan napas, jauhkan Turbuhaler®

6. Letakkan mouthpiece diantara mulut dan katupkan bibir

7. Bernapaslah dengan kuat dan dalam 
8. Tahan napas 5-10 detik

9. Hembuskan napas dan jauhkan Turbuhaler ${ }^{\circledR}$ dari mulut

10. Kumur-kumur dengan air bersih dan jangan ditelan

Uji validitas digunakan untuk mengukur valid atau tidaknya suatu kuesioner. Validasi checklist dilakukan untuk menyamakan persepsi antar peneliti dengan satu orang teman yang menilai pada saat subjek penelitian memperagakan cara penggunaan inhaler. Sebelumnya telah dilakukan uji validitas dengan menggunakan pearson yang mengkorelasikan antara skor masing-masing item dengan skor total yang diperoleh dalam penelitian. Jika ada item yang tidak memenuhi syarat maka item tersebut tidak dianalisa lebih lanjut. Nilai pearson correlation (rtabel $=0,244$ ) lebih besar dari r-tabel, sehingga dinyatakan valid. Selanjutnya pengisian form checklist dilakukan oleh tim penilai (minimal 2 orang) dengan cara mengamati langsung pada saat subjek menjelaskan penggunaan alat inhaler.

Penilaian dilakukan dengan memberikan alat inhaler kepada subjek sebelum (pre-) dan sesudah (post-) pemberan edukasi video. Data yang telah diperoleh kemudian dievaluasi berdasarkan dengan "nilai setiap tahapan" dan "total score" yang telah diisi oleh tim penilai (minimal 2 orang). Masing-masing nilai benar untuk satu tahapan sesuai dengan yang dijelaskan dan diperagakan oleh subjek adalah 1 , sehingga jika ditotal dan dihitung rata-ratanya didapatkan hasil penilaian secara verbal dan motoriknya masingmasing adalah 1. Jika yang dijelaskan dan yang diperagakan subjek tidak tepat sesuai dengan checklist, masing-masing nilainya adalah 0,5. Sedangkan apabila subjek tidak menjelaskan atau tidak memperagakan apapun, masing-masing nilainya adalah 0 .

Dari hasil data yang diperoleh, masing-masing penilaian secara verbal (yang dijelaskan oleh subjek) dan penilaian secara motorik (yang diperagakan oleh subjek) dilihat dari pre- dan post-intervensi. Edukasi cara penggunaan inhaler dalam bentuk video efektif apabila pre- dan postintervensi dari masing-masing penilaian secara verbal dan motorik menunjukkan hasil berbeda bermakna dan subjek dapat menjelaskan serta memperagakan semua tahapan cara penggunaan inhaler dengan benar. Uji statistika normalitas menggunakan Shapiro-Wilk, apabila nilai $\mathrm{p}>0,05$ maka data terdistribusi normal sehingga dapat dilakukan uji t-test. Sedangkan apabila nilai $\mathrm{p}<0,05$ maka data tidak terdistribusi normal, sehingga dapat dilakukan uji non parametrik Mann-Whitney.

\section{HASIL DAN PEMBAHASAN}

Penelitian dilaksanakan di wilayah Surabaya. Jumlah subjek pada penelitian ini adalah 180 orang, terdiri dari subjek kelompok Diskus ${ }^{\circledR}$ dan Turbuhaler®. Jumlah subjek penelitian pada kelompok uji Diskus ${ }^{\circledR}$ sebanyak 45 orang dan kelompok uji Turbuhaler® sebanyak 45 orang. Jumlah subjek penelitian pada kelompok pembanding Diskus ${ }^{\circledR}$ sebanyak 45 orang dan kelompok pembanding Turbuhaler ${ }^{\circledR}$ sebanyak 45 orang.

\section{Uji Reabilitas}

Uji reliabilitas pada penelitian ini menggunakan Cohen's Kappa. Uji ini digunakan untuk mengukur konsistensi pengukuran yang dilakukan dua orang penilai. Reliabilitas menunjukkan konsistensi suatu alat pengukur di dalam pengukur gejala yang sama. Instrument dinyatakan reliabel jika nilai Cohen's Kappa > 0,6 (Tabel 1).

\section{Kelengkapan Informasi yang Diberikan Subjek Penelitian}

Data kelengkapan informasi cara penggunaan inhaler dapat dilihat pada Tabel 2, 
yang ditampilkan dalam dua penilaian yaitu verbal dan motorik.

Berdasarkan uji normalitas di Tabel 3, data tidak terditribusi normal sehingga dilakukan analisis non-parametrik menggunakan uji non-parametrik MannWhitney Test yang bertujuan untuk mengetahui pengaruh antara variabel bebas dan variabel terikat. Tabel 4 adalah hasil uji beda dari masing-masing inhaler dan dapat disimpulkan bahwa edukasi video inhaler jenis MDI, MDI dengan spacer, Diskus ${ }^{\circledR}$ dan Turbuhaler efektif memberikan perubahan yang signifikan (nilai P 4,05 ) baik pada penjelasan secara verbal dan motorik.

Tabel 1. Uji Reabilitas Checklist Inhaler

\begin{tabular}{lccc}
\hline \multicolumn{1}{c}{ Alat inhaler } & Nilai Cohen's Kappa & $\begin{array}{c}\text { Jumlah tahapan } \\
\text { penggunaan }\end{array}$ & Kesimpulan \\
\hline MDI & 0,615 & 8 & Reliabel \\
MDI dengan spacer & 0,777 & 11 & Reliabel \\
Diskus $^{\circledR}$ & 0,615 & 9 & Reliabel \\
Turbuhaler $^{\circledR}$ & 0,793 & 10 & Reliabel \\
\hline
\end{tabular}

Tabel 2. Distribusi Frekuensi Kelengkapan Informasi Cara Penggunaan masing- masing Inhaler

\begin{tabular}{|c|c|c|c|c|c|c|c|c|c|c|c|c|}
\hline \multirow{3}{*}{ Alat Inhaler: } & & \multirow{3}{*}{ Tahapan } & \multicolumn{10}{|c|}{ Jumlah Subjek Penelitian } \\
\hline & & & \multicolumn{5}{|c|}{ Penilaian Verbal } & \multicolumn{5}{|c|}{ Penilaian Motorik } \\
\hline & & & $\begin{array}{c}\text { Nilai : } \\
0\end{array}$ & $\begin{array}{l}\text { Nilai: } \\
0,5\end{array}$ & $\begin{array}{c}\text { Nilai : } \\
1\end{array}$ & $\begin{array}{c}\text { Rata- } \\
\text { rata }\end{array}$ & SD & $\begin{array}{c}\text { Nilai: } \\
0\end{array}$ & $\begin{array}{c}\text { Nilai: } \\
0,5\end{array}$ & $\begin{array}{c}\text { Nilai: } \\
1\end{array}$ & $\begin{array}{c}\text { Rata- } \\
\text { rata }\end{array}$ & SD \\
\hline \multirow{16}{*}{ MDI (n: 45) } & \multirow{8}{*}{ Pre- } & 1 & 4 & 25 & 16 & 0,6 & 0,3 & 2 & 5 & 38 & 0,9 & 0,3 \\
\hline & & 2 & 16 & 15 & 14 & 0,5 & 0,4 & 16 & 13 & 16 & 0,5 & 0,4 \\
\hline & & 3 & 8 & 16 & 21 & 0,6 & 0,4 & 8 & 15 & 22 & 0,7 & 0,4 \\
\hline & & 4 & 19 & 9 & 17 & 0,5 & 0,5 & 14 & 11 & 20 & 0,6 & 0,4 \\
\hline & & 5 & 32 & 9 & 4 & 0,2 & 0,3 & 31 & 9 & 5 & 0,2 & 0,3 \\
\hline & & 6 & 5 & 11 & 29 & 0,8 & 0,3 & 6 & 14 & 25 & 0,7 & 0,4 \\
\hline & & 7 & 2 & 16 & 27 & 0,8 & 0,3 & 4 & 19 & 22 & 0,7 & 0,3 \\
\hline & & 8 & 16 & 9 & 19 & 0,5 & 0,4 & 16 & 13 & 16 & 0,5 & 0,4 \\
\hline & \multirow{8}{*}{ Post- } & 1 & 0 & 5 & 40 & 0,9 & 0,2 & 0 & 0 & 45 & 1,0 & 0 \\
\hline & & 2 & 0 & 3 & 42 & 1,0 & 0,1 & 1 & 2 & 42 & 1,0 & 0,2 \\
\hline & & 3 & 1 & 3 & 41 & 0,9 & 0,2 & 2 & 2 & 41 & 0,9 & 0,2 \\
\hline & & 4 & 10 & 10 & 25 & 0,7 & 0,4 & 4 & 5 & 36 & 0,9 & 0,3 \\
\hline & & 5 & 11 & 13 & 21 & 0,6 & 0,4 & 9 & 12 & 24 & 0,7 & 0,4 \\
\hline & & 6 & 1 & 6 & 38 & 0,9 & 0,2 & 0 & 6 & 39 & 0,9 & 0,2 \\
\hline & & 7 & 0 & 4 & 41 & 1,0 & 0,1 & 0 & 3 & 42 & 1,0 & 0,1 \\
\hline & & 8 & 0 & 7 & 38 & 0,9 & 0,2 & 0 & 13 & 32 & 0,9 & 0,2 \\
\hline \multirow{7}{*}{$\begin{array}{l}\text { MDI dengan Spacer } \\
\quad(n: 45)\end{array}$} & \multirow{7}{*}{ Pre- } & 1 & 4 & 19 & 22 & 0,7 & 0,3 & 1 & 4 & 40 & 0,9 & 0,2 \\
\hline & & 2 & 15 & 22 & 8 & 0,4 & 0,3 & 15 & 20 & 10 & 0,4 & 0,4 \\
\hline & & 3 & 16 & 25 & 4 & 0,4 & 0,3 & 16 & 23 & 6 & 0,4 & 0,3 \\
\hline & & 4 & 25 & 10 & 10 & 0,3 & 0,4 & 19 & 11 & 15 & 0,5 & 0,4 \\
\hline & & 5 & 3 & 5 & 37 & 0,9 & 0,3 & 2 & 9 & 34 & 0,9 & 0,3 \\
\hline & & 6 & 10 & 13 & 22 & 0,6 & 0,4 & 8 & 16 & 21 & 0,6 & 0,4 \\
\hline & & 7 & 24 & 5 & 16 & 0,4 & 0,5 & 28 & 7 & 9 & 0,3 & 0,4 \\
\hline
\end{tabular}




\begin{tabular}{|c|c|c|c|c|c|c|c|c|c|c|c|c|}
\hline \multirow{3}{*}{ Alat Inhaler: } & & \multirow{3}{*}{ Tahapan } & \multicolumn{10}{|c|}{ Jumlah Subjek Penelitian } \\
\hline & & & \multicolumn{5}{|c|}{ Penilaian Verbal } & \multicolumn{5}{|c|}{ Penilaian Motorik } \\
\hline & & & $\begin{array}{c}\text { Nilai : } \\
0 \\
\end{array}$ & $\begin{array}{c}\text { Nilai: } \\
0,5 \\
\end{array}$ & $\begin{array}{c}\text { Nilai : } \\
1 \\
\end{array}$ & $\begin{array}{c}\text { Rata- } \\
\text { rata }\end{array}$ & SD & $\begin{array}{c}\text { Nilai: } \\
0 \\
\end{array}$ & $\begin{array}{c}\text { Nilai: } \\
0,5 \\
\end{array}$ & $\begin{array}{c}\text { Nilai: } \\
1 \\
\end{array}$ & $\begin{array}{c}\text { Rata- } \\
\text { rata }\end{array}$ & SD \\
\hline & & 8 & 4 & 20 & 21 & 0,7 & 0,3 & 4 & 22 & 18 & 0,7 & 0,3 \\
\hline & & 9 & 11 & 12 & 22 & 0,6 & 0,4 & 11 & 14 & 20 & 0,6 & 0,4 \\
\hline & & 10 & 2 & 23 & 20 & 0,7 & 0,3 & 3 & 22 & 20 & 0,7 & 0,3 \\
\hline & & 11 & 25 & 8 & 12 & 0,4 & 0,4 & 29 & 6 & 10 & 0,3 & 0,4 \\
\hline & & 1 & 0 & 2 & 43 & 1,0 & 0,1 & 0 & 0 & 45 & 1,0 & 0 \\
\hline & & 2 & 1 & 8 & 36 & 0,9 & 0,2 & 1 & 6 & 38 & 0,9 & 0,2 \\
\hline & & 3 & 1 & 18 & 26 & 0,8 & 0,3 & 1 & 13 & 31 & 0,8 & 0,3 \\
\hline & & 4 & 8 & 9 & 28 & 0,7 & 0,4 & 9 & 6 & 30 & 0,7 & 0,4 \\
\hline & & 5 & 1 & 2 & 42 & 1,0 & 0,2 & 1 & 1 & 43 & 1,0 & 0,2 \\
\hline & & 6 & 3 & 6 & 36 & 0,9 & 0,3 & 4 & 7 & 34 & 0,8 & 0,3 \\
\hline & & 7 & 7 & 4 & 34 & 0,8 & 0,4 & 6 & 7 & 32 & 0,8 & 0,4 \\
\hline & & 8 & 0 & 6 & 39 & 0,9 & 0,2 & 0 & 4 & 41 & 1,0 & 0,1 \\
\hline & & 9 & 1 & 6 & 38 & 0,9 & 0,2 & 1 & 5 & 39 & 0,9 & 0,2 \\
\hline & & 10 & 1 & 3 & 41 & 0,9 & 0,2 & 0 & 3 & 42 & 1,0 & 0,1 \\
\hline & & 11 & 2 & 9 & 34 & 0,9 & 0,3 & 2 & 10 & 33 & 0,8 & 0,3 \\
\hline \multirow{18}{*}{ Diskus $^{\circledR}$ (n: 45) } & \multirow{9}{*}{ Pre- } & 1 & 4 & 28 & 13 & 0,6 & 0,3 & 1 & 8 & 36 & 0,9 & 0,2 \\
\hline & & 2 & 6 & 25 & 14 & 0,6 & 0,3 & 6 & 12 & 27 & 0,7 & 0,4 \\
\hline & & 3 & 37 & 6 & 2 & 0,1 & 0,3 & 36 & 6 & 3 & 0,1 & 0,3 \\
\hline & & 4 & 18 & 18 & 9 & 0,4 & 0,4 & 18 & 20 & 7 & 0,4 & 0,4 \\
\hline & & 5 & 11 & 28 & 6 & 0,4 & 0,3 & 14 & 26 & 5 & 0,4 & 0,3 \\
\hline & & 6 & 0 & 26 & 19 & 0,7 & 0,3 & 3 & 33 & 9 & 0,6 & 0,3 \\
\hline & & 7 & 10 & 11 & 24 & 0,7 & 0,4 & 15 & 25 & 5 & 0,4 & 0,3 \\
\hline & & 8 & 9 & 29 & 7 & 0,5 & 0,3 & 11 & 28 & 6 & 0,4 & 0,3 \\
\hline & & 9 & 1 & 34 & 10 & 0,6 & 0,2 & 2 & 8 & 35 & 0,9 & 0,3 \\
\hline & \multirow{9}{*}{ Post- } & 1 & 0 & 1 & 44 & 1,0 & 0,1 & 0 & 0 & 45 & 1,0 & 0,0 \\
\hline & & 2 & 0 & 0 & 45 & 1,0 & 0,0 & 0 & 0 & 45 & 1,0 & 0,0 \\
\hline & & 3 & 20 & 1 & 24 & 0,5 & 0,5 & 18 & 1 & 26 & 0,6 & 0,5 \\
\hline & & 4 & 0 & 7 & 38 & 0,9 & 0,2 & 0 & 11 & 34 & 0,9 & 0,2 \\
\hline & & 5 & 1 & 14 & 30 & 0,8 & 0,3 & 1 & 20 & 24 & 0,8 & 0,3 \\
\hline & & 6 & 0 & 3 & 42 & 1,0 & 0,1 & 0 & 9 & 36 & 0,9 & 0,2 \\
\hline & & 7 & 0 & 1 & 44 & 1,0 & 0,1 & 0 & 19 & 26 & 0,8 & 0,3 \\
\hline & & 8 & 0 & 11 & 34 & 0,9 & 0,2 & 0 & 9 & 36 & 0,9 & 0,2 \\
\hline & & 9 & 0 & 2 & 43 & 1,0 & 0,1 & 0 & 0 & 45 & 1,0 & 0,0 \\
\hline \multirow{5}{*}{ Turbuhaler $^{\circledR}$ (n: 45) } & \multirow{5}{*}{ Pre- } & 1 & 0 & 31 & 14 & 0,7 & 0,2 & 0 & 0 & 45 & 1,0 & 0,0 \\
\hline & & 2 & 38 & 0 & 7 & 0,2 & 0,4 & 37 & 0 & 8 & 0,2 & 0,4 \\
\hline & & 3 & 6 & 19 & 20 & 0,7 & 0,4 & 7 & 18 & 20 & 0,6 & 0,4 \\
\hline & & 4 & 15 & 24 & 6 & 0,4 & 0,3 & 20 & 21 & 4 & 0,3 & 0,3 \\
\hline & & 5 & 27 & 15 & 3 & 0,2 & 0,3 & 28 & 12 & 5 & 0,2 & 0,3 \\
\hline
\end{tabular}




\begin{tabular}{|c|c|c|c|c|c|c|c|c|c|c|c|c|}
\hline \multirow{3}{*}{ Alat Inhaler: } & & \multirow{3}{*}{ Tahapan } & \multicolumn{10}{|c|}{ Jumlah Subjek Penelitian } \\
\hline & & & \multicolumn{5}{|c|}{ Penilaian Verbal } & \multicolumn{5}{|c|}{ Penilaian Motorik } \\
\hline & & & $\begin{array}{c}\text { Nilai : } \\
0 \\
\end{array}$ & $\begin{array}{c}\text { Nilai: } \\
0,5\end{array}$ & $\begin{array}{c}\text { Nilai : } \\
1 \\
\end{array}$ & $\begin{array}{c}\text { Rata- } \\
\text { rata }\end{array}$ & SD & $\begin{array}{c}\text { Nilai: } \\
0 \\
\end{array}$ & $\begin{array}{c}\text { Nilai: } \\
0,5 \\
\end{array}$ & $\begin{array}{c}\text { Nilai: } \\
1 \\
\end{array}$ & $\begin{array}{c}\text { Rata- } \\
\text { rata }\end{array}$ & SD \\
\hline & & 6 & 20 & 23 & 2 & 0,3 & 0,3 & 18 & 25 & 2 & 0,3 & 0,3 \\
\hline & & 7 & 3 & 20 & 22 & 0,7 & 0,3 & 2 & 27 & 16 & 0,7 & 0,3 \\
\hline & & 8 & 9 & 15 & 21 & 0,6 & 0,4 & 13 & 30 & 2 & 0,4 & 0,3 \\
\hline & & 9 & 3 & 38 & 4 & 0,5 & 0,2 & 4 & 34 & 7 & 0,5 & 0,2 \\
\hline & & 10 & 27 & 14 & 4 & 0,2 & 0,3 & 30 & 13 & 2 & 0,2 & 0,3 \\
\hline & Post- & 1 & 0 & 5 & 40 & 0,9 & 0,2 & 0 & 0 & 45 & 1,0 & 0,0 \\
\hline & & 2 & 10 & 6 & 29 & 0,7 & 0,4 & 7 & 5 & 33 & 0,8 & 0,4 \\
\hline & & 3 & 0 & 0 & 45 & 1,0 & 0,0 & 0 & 3 & 42 & 1,0 & 0,1 \\
\hline & & 4 & 0 & 13 & 32 & 0,9 & 0,2 & 0 & 16 & 29 & 0,8 & 0,2 \\
\hline & & 5 & 0 & 13 & 32 & 0,9 & 0,2 & 0 & 9 & 36 & 0,9 & 0,2 \\
\hline & & 6 & 2 & 14 & 29 & 0,8 & 0,3 & 2 & 15 & 28 & 0,8 & 0,3 \\
\hline & & 7 & 0 & 3 & 42 & 1,0 & 0,1 & 0 & 4 & 41 & 1,0 & 0,1 \\
\hline & & 8 & 0 & 2 & 43 & 1,0 & 0,1 & 0 & 24 & 21 & 0,7 & 0,3 \\
\hline & & 9 & 0 & 9 & 36 & 0,9 & 0,2 & 0 & 7 & 38 & 0,9 & 0,2 \\
\hline & & 10 & 2 & 15 & 28 & 0,8 & 0,3 & 3 & 13 & 29 & 0,8 & 0,3 \\
\hline
\end{tabular}

\section{Keterangan:}

Motorik : kemampuan subjek memperagakan step cara penggunaan inhaler

Verbal : kemampuan subjek menjawab dengan step cara penggunaan inhaler

Verbal \& Motorik : kemampuan subjek dalam memperagakan dan menjawab dengan benar step cara penggunaan inhaler

Tabel 3. Uji Normalitas Data dari Masing-masing Inhaler

\begin{tabular}{lccc}
\hline \multirow{2}{*}{ Alat Inhaler } & & \multicolumn{2}{c}{ Shapiro-Wilk Test } \\
\cline { 2 - 4 } & & Sig. & Kesimpulan \\
\cline { 2 - 4 } & & 0,001 & Tidak normal \\
\cline { 2 - 4 } MDI & Pre- & 0,000 & Tidak normal \\
\cline { 2 - 4 } & Post- & 0,001 & Tidak normal \\
\hline Diskus $^{\circledR}$ & Post- & 0,000 & Tidak normal \\
\cline { 2 - 4 } & Pre- & 0,000 & Tidak normal \\
\hline Turbuhaler $^{\circledR}$ & Post- & 0,000 & Tidak normal \\
\cline { 2 - 4 } & Pre- & 0,000 & Tidak normal \\
\hline
\end{tabular}

Tabel 4. Uji Beda dari Masing-masing Inhaler

\begin{tabular}{lcccc}
\hline \multicolumn{4}{c}{ Mann-Whitney Test } \\
\hline & \multicolumn{2}{c}{ Penilaian Verbal } & \multicolumn{2}{c}{ Penilaian Motorik } \\
\hline & Nilai P & Kesimpulan & Nilai P & kesimpulan \\
\hline MDI & 0,000 & $\mathrm{H}_{\mathrm{a}}$ Diterima & 0,000 & $\mathrm{H}_{\mathrm{a}}$ Diterima \\
MDI dengan Spacer & 0,000 & $\mathrm{H}_{\mathrm{a}}$ Diterima & 0,000 & $\mathrm{H}_{\mathrm{a}}$ Diterima \\
Diskus $^{\circledR}$ & 0,000 & $\mathrm{H}_{\mathrm{a}}$ Diterima & 0,000 & $\mathrm{H}_{\mathrm{a}}$ Diterima \\
Turbuhaler $^{\circledR}$ & 0,000 & $\mathrm{H}_{\mathrm{a}}$ Diterima & 0,000 & $\mathrm{H}_{\mathrm{a}}$ Diterima \\
\hline
\end{tabular}

$\mathrm{H}_{\mathrm{a}}$ diterima jika nilai $\mathrm{P} \unlhd 0,05$, maka ada perbedaan sebelum dan sesudah pemberian intervensi berupa video 
Menurut PERMENKES RI Nomor 1023/MENKES/SK/XI/2008 (28) tentang Pedoman Pengendalian Penyakit Asma bahwa perlu dilakukan peningkatan upaya pengendalian penyakit asma dengan menyusun kebijakan teknis, standarisasi, bimbingan teknis, pemantauan, dan evaluasi di bidang penyakit asma sehingga sangat diperlukan peran apoteker di dalamnya. Seorang apoteker dalam program pengendalian asma dapat memberikan penyuluhan (KIE), melakukan kemitraan, perlindungan khusus, upaya peningkatan peran serta masyarakat dalam pencegahan dan penanggulangan asma, serta pemantauan dan penilaian.

Penggunaan inhaler dapat tercapai dengan baik dan tepat dengan pemberian pengetahuan yang diberikan sejak dini kepada mahasiswa apoteker karena penggunaan inhaler tidak cukup jika hanya diberikan secara konsep materi saja tetapi juga diperlukan contoh atau praktek dalam pengggunaan alat inhaler tersebut (24). Menurut penelitian yang dilakukan oleh Basheti et al. (2015) ${ }^{(24)}$ menunjukkan bahwa sebagian besar mahasiswa (78\%) diyakini kurangnya latihan dalam penggunaan inhaler merupakan penghalang utama dalam perbaikan penggunaan inhaler. Semua mahasiswa (100\%) percaya bahwa mereka berperan untuk memberikan edukasi kepada pasien terkait cara penggunaan inhaler dengan tepat supaya dapat mencapai hasil terapi yang optimal.

Pada penggunaan DPI dapat lebih mudah dilakukan karena DPI tidak mengandung propelan dan semua perangkatnya memerlukan upaya inspirasi dari pasien untuk menghantarkan bubuk obat sehingga tidak memerlukan koordinasi dalam penggunaannya dan mengakibatkan deposisi obat di dalam paru-paru lebih tinggi dan lebih konstan dibandingkan MDI ${ }^{(29,30)}$. Penggunaan semua inhaler jenis DPI memerlukan teknik pengambilan nafas dengan benar sehingga hanya dapat digunakan oleh anak dan orang dewasa. Konsentrasi partikel ICS (Inhaled Corticosteroid) yang relatif tinggi akan aktif dalam saluran udara ${ }^{(31)}$. Massa partikel obat yang cukup kecil untuk mencapai saluran udara selama inhalasi yang disebut fine particle fraction (FPF) akan mempengaruhi deposisi obat di dalam paru-paru. Ukuran partikel obat <5 m akan terdeposit dan memberikan efek yang optimal pada saluran pernafasan. Kelebihan lain dari DPI yaitu kemasannya kecil sehingga mudah dibawa dan penggunaannya cepat ${ }^{(4,28)}$.

Price et al. (2013) ${ }^{(32)}$ menyebutkan bahwa untuk mendapatkan efek yang optimal, teknik yang digunakan pada saat penggunaan DPI harus tepat dan benar. Namun, berbagai kesalahan kritis dilakukan pasien saat menggunakan DPI diantaranya inhalasi yang dilakukan tidak kuat sejak awal dan inhalasi dilakukan melalui hidung. Hal ini dibuktikan oleh Lee et al. (2011) ${ }^{(33)}$ yang menyebutkan dari 78 pasien asma berusia $\geq 13$ tahun di Korea Selatan yang menggunakan Diskus ${ }^{\circledR}$ menunjukkan bahwa sebanyak $6,2 \%$ pasien pengguna Diskus ${ }^{\circledR}$ dan sebanyak $12,8 \%$ pasien pengguna Turbuhaler® tidak memenuhi teknik adekuat sehingga pengobatan asma menjadi tidak optimal. Jika terjadi kesalahan dalam penggunaan Diskus ${ }^{\circledR}$ dan Turbuhaler ${ }^{\circledR}$, mengakibatkan biaya yang dikeluarkan untuk membeli Diskus ${ }^{\circledR}$ dan Turbuhaler ${ }^{\circledR}$ menjadi lebih mahal ${ }^{(\mathbf{1 4})}$.

Total skor ini didapatkan dari penjumlahan skor pada setiap step saat subyek memperagakan penggunaan alat inhaler, baik dari penilaian secara verbal (pada saat menjelaskan), penilaian motorik (pada saat mempegarakan), serta penilaian verbal (pada saat menjelaskan) dan penilaian motorik (pada saat mempegarakan). Nantinya, nilai rata-rata dari total skor pada kelompok pembanding (test) dan kelompok uji (pre-test) dijadikan kriteria untuk 
menetapkan tingkat kemampuan subyek dalam menjelaskan (verbal), memperagakan (motorik), serta menjelaskan (verbal) dan memperagakan (motorik). Nilai tersebut digunakan sebagai acuan karena subyek telah menyelesaikan perkuliahan S-1 dan telah atau masih mengambil profesi apoteker di Universitas Surabaya, mengingat bahwa di perkuliahan tersebut telah diajarkan cara penggunaan alat inhaler khususnya Diskus ${ }^{\circledR}$ dan Turbuhaler®.

Kemampuan verbal adalah kecakapan dan kesanggupan seseorang dalam menjelaskan sesuatu secara lisan (bukan tertulis). Sedangkan kemampuan motorik adalah proses perantara antara stimulus dan respon. Sehingga dapat diartikan kemampuan verbal dan motorik adalah kecakapan dan kesanggupan seseorang dalam menjelaskan secara lisan sekaligus memperagakan/ memberikan respon terhadap suatu hal. Pada penelitian ini, pemberian informasi terkait cara penggunaan inhaler dilakukan dengan cara dijelaskan (verbal) maupun diperagakan (motorik). Oleh karena itu, untuk menunjang pengetahuan mahasiswa apoteker diperlukan media audio visual. Media audio visual adalah jenis media yang digunakan dalam kegiatan pembelajaran dengan melibatkan pendengaran dan penglihatan sekaligus dalam satu proses atau kegiatan. Pesan dan informasi yang disalurkan melalui media ini dapat berupa pesan verbal dan non verbal yang mengandalkan penglihatan maupun pendengaran. Beberapa contoh media audio visual adalah film, video, program TV dan lain-lain. Kemampuan media ini dianggap lebih baik dan lebih menarik dibandingkan apabila hanya dijelaskan atau diperagakan saja. Kesulitan dalam penilaian ini yaitu, dimana sebagian besar subjek penelitian kurang lengkap dalam menjelaskan (verbal) tetapi dapat memperagakan (motorik) dengan baik dan subjek penelitian lengkap saat menjelaskan (verbal), namun tidak memperagakan (motorik) apapun. Selain itu pada saat menjelaskan, juga banyak subjek penelitian yang terbalik-balik step nya (tidak urut sesuai critical step) bahkan ada juga subjek penelitian yang menyebutkan banyak hal saat menjelaskan dan memperagakan.

Edukasi video diberikan untuk menunjang pembelajaran terkait cara penggunaan inhaler dikarenakan sebagian besar subyek penelitian masih kesulitan dalam hal menjelaskan dan memperagakan cara penggunaan inhaler walaupun sudah mendapatkan materi cara penggunaan inhaler saat perkuliahan, baik di S-1 maupun profesi apoteker. Video ini merupakan salah satu media pendukung untuk mencapai tujuan pembelajaran.

Pada hasil uji beda ini menggunakan analisis non-parametik yaitu mann-whitney test, dan didapatkan hasil bahwa Ha diterima (p $₫$,05). Hal ini dapat disimpulkan bahwa terdapat perbedaan sebelum dan sesudah pemberian edukasi video. Ada beberapa faktor yang dapat mempengaruhi hasil uji ini yaitu: (1) pada saat menjelaskan penggunaan inhaler, ada subyek yang berdiskusi dengan subyek lain sehingga dapat mempengaruhi pengetahuan subyek yang sedang menjelaskan penggunaan inhaler, (2) subyek kurang memperhatikan pada saat penayangan video.

Penggunaan inhaler yang tidak tepat dapat menyebabkan partikel obat yang terhirup tidak maksimal sehingga pengobatan yang dilakukan menjadi tidak optimal dan selanjutnya dapat menyebabkan eksaserbasi asma yang mengancam jiwa. Pendidikan yang diberikan kepada mahasiswa farmasi terkait cara penggunaan inhaler, lebih baik diberikan sedini mungkin supaya nantinya dapat menghasilkan apoteker yang kompeten di bidangnya.

Pada penelitian yang dilakukan oleh Basheti et al. (2015) ${ }^{(24)}$ menunjukkan bahwa sebagian besar mahasiswa (78\%) meyakini kurangnya latihan saat penggunakan 
perangkat inhaler merupakan penghalang utama dalam memperbaiki penggunaan inhaler. Mayoritas mahasiswa (95,4\%) percaya bahwa itu adalah peran mereka sebagai apoteker untuk mengidentifikasi pasien dengan masalah kesehatan yang timbul akibat dari kesalahan penggunaan pengobatan. Semua mahasiswa (100\%) percaya bahwa itu adalah peran mereka untuk menunjukkan kepada pasien penggunaan yang benar dari perangkat inhaler yang sedang mereka gunakan ${ }^{(23)}$.

Pembelajaran terkait penggunaan inhaler dilakukan di Universitas Surabaya pada saat praktikum, melalui penjelasan dosen serta menggunakan alat peraga. Setiap mahasiswa farmasi yang mengikuti praktikum dapat melihat dan mencoba cara penggunaan masing-masing alat inhaler secara bergiliran. Selain itu, ada sesi kasus dimana ada seorang mahasiswa yang berperan sebagai seorang apoteker dan ada mahasiswa lagi yang berperan sebagai pasien di suatu apotek. Mahasiswa yang berperan sebagai apoteker bertugas untuk menunjukkan langkah-langkah cara penggunaan salah satu alat inhaler pada mahasiswa yang berperan sebagai pasien.

\section{SIMPULAN}

Penelitian ini dilakukan untuk mengetahui efektivitas pemberian edukasi video kepada mahasiswa profesi apoteker. Berdasarkan penelitian ini, menunjukkan bahwa edukasi video cara penggunaan beberapa jenis inhaler (MDI, MDI dan spacer, Diskus®, dan Turbuhaler®) terbukti efektif meningkatkan kemampuan mahasiswa apoteker yang dinilai dari kelengkapan penjelasan cara penggunaan inhaler tersebut, baik secara verbal dan motorik. Selain itu, berdasarkan penelitian yang dilakukan terkait kelengkapan penjelasan cara penggunaan inhaler pada kelompok pembanding dan uji pre-test, menunjukkan bahwa tidak ada satu pun apoteker $(0 \%)$ yang mampu menjelaskan semua step dengan tepat sesuai dengan langkah-langkah cara penggunaan inhaler.

\section{UCAPAN TERIMA KASIH}

Terima kasih kepada Lembaga Penelitian dan Pengabdian kepada Masyarakat Universitas Surabaya (LPPM UBAYA) atas dukungan dana dan kepada Fakutas Farmasi Universitas Surabaya atas support fasilitas sarana-prasarana.

\section{DAFTAR PUSTAKA}

1. Global Initiative for Asthma, 2018, Global Strategy for Ashtma Management and Prevention.

2. Kemenkes, 2014, Riset Kesehatan Dasar Tahun 2018, Kementrian Kesehatan Republik Indonesia, Jakarta.

3. Voshaar, T., Spinola, M., Linnane, P., Campanini, A., Lock, D., Lafratta, A., Scuri M, Ronca B, Melani, A.S., 2014, Comparing usability of NEXThaler ${ }^{\circledR}$ with other inhaled corticosteroid/longacting $\beta 2$-agonist fixed combination dry powder inhalers in asthma patients, Journal of aerosol medicine and pulmonary drug delivery, 27(5):363-70.

4. Lorensia, A., Suryadinata, R.V., 2018, Panduan Lengkap Penggunaan Macam-Macam Alat Inhaler pada Gangguan Pernafasan, CV M-Brothers, Surabaya.

5. Jahedi, L., Downie, S.R., Saini, B., Chan, H.K., Bosnic-Anticevich, S., 2017, Inhaler Technique in Asthma: How Does It Relate to Patients' Preferences and Attitudes Toward Their Inhalers?, J Aerosol Med Pulm Drug Deliv., 30(1):42-52.

6. Usmani, O.S., 2019, Choosing the right inhaler for your asthma or COPD patient, Ther Clin Risk Manag., 15:461-72.

7. Chogtu, B., Holla, S., Magazine, R., Kamath, A., 2017, Evaluation of 
relationship of inhaler technique with asthma control and quality of life, Indian J Pharmacol., 49(1):110 115 .

8. Ditjen Binfar \& alkes, 2007, Pharmaceutical Care Untuk Penyakit Asma, Departemen Kesehatan RI, Jakarta.

9. Godara, N., Godara, R., Khullar, M., 2011, Impact of inhalation therapy on oral health, Lung India, 28(4):272-275.

10. Erdoğan, T., Karakaya, G., Kalyoncu, A.F., 2019, The Frequency and Risk Factors for Oropharyngeal Candidiasis in Adult Asthma Patients Using Inhaled Corticosteroids, Turk Thorac J., 20(2):136-139.

11. Al-Jahdali, H., Ahmed, A., Al-Harbi, A., Khan, M., et al., 2013, Improper inhaler technique is associated with poor asthma control and frequent emergency department visits, Allergy Asthma Clin Immunol., 9(8):1-7.

12. Arora, P., Kumar, L., Vohra, V., Sarin, R., Jaiswal, A., Puri, M.M., Rathee, D., Chakraborty, P., 2014, Evaluating the technique of using inhalation device in COPD and Bronchial Asthma patients, Respiratory Medicine, 108(7):992-8.

13. Hashmi, A., Soomro, J., Memon, A., Soomro, T.. 2012, Incorrect Inhaler Technique Compromising Quality of Life of Asthmatic Patients, Journal of Medicine, 13(1):16-21.

14. Meltzer, E.O., Busse, W.W., Wenzel, S.E., Belozeroff, V., Weng, H.H., Feng, J., et al., 2011, Use of the Asthma Control Questionnaire to predict future risk of asthma exacerbation, J Allergy Clin Immunol., 127(1):167-72.

15. Price, D., Haughney, J., Sims, E., et al., 2011, Effectiveness of inhaler types for real-world asthma management: retrospective observational study using the GPRD, J Asthma Allergy, 4:37-47.
16. Abdullah, A., Andrajati, Supardi, S., 2010, Pengetahuan, Sikap Dan Kebutuhan Pengunjung Apotek Terhadap Informasi Obat Di Kota Depok, Buletin Penelitian Sistem Kesehatan, 13(4):344-52.

17. Odili, V.U., Okoribe, C.O., 2010, Assessment of Pharmacists' knowledge on correct inhaler technique, Research Journal of Pharmaceutical, Biological and Chemical Sciences, 1(3):768-72.

18. Osman, A., Hasaan, I.S.A., Ibrahim, M.I.M., 2012, Are Sudanese Community Pharmacists Capable to Prescribe and Demonstrate Asthma Inhaler Device to patron A mystery study, Pharmacy Pratice Granada, 10(2):110-5.

19. Lorensia, A., Queljoe, D.D., Karina, B.L., Hewu, A., 2016, Studi Kelengkapan Penjelasan Cara Penggunaan Sediaan Controller Inhaler (Kombinasi Kortikosteroid Dengan Beta-2 Agonis) Jenis Diskus ${ }^{\circledR}$ dan Turbuhaler $^{\circledR}$ Oleh Apoteker di Apotek, Jurnal Ilmiah Manuntung (JIM) Sains Farmasi dan Kesehatan, Akademi Farmasi Samarinda, 2(2):137-46.

20. Lorensia, A., Queljoe, D.D., Tandjung, Y.C.W., 2019, Profil Kelengkapan Informasi oleh Apoteker Tentang Cara Penggunaan Sediaan Handihaler ${ }^{\circledR}$ yang Mengandung Tiotropium Bromida di Apotek Wilayah Surabaya Timur, Jurnal Sains dan Kesehatan (JSK), UNMUL, 2(1):25-39.

21. Lorensia, A., Nathania, J., 2017, Studi Kelengkapan Penjelasan Informasi Cara Penggunaan Controller Metered-Dose Inhaler (MDI) yang Mengandung Kortikosteroid sebagai Terapi Asma di Apotek Kabupaten Tuban, Jurnal Ilmiah Manuntung (JIM) Sains Farmasi dan Kesehatan, Akademi Farmasi Samarinda, 3(1):14-25. 
22. Lorensia, A., Queljoe, D.D., Valensia, Y., 2018, Karakteristik Informasi Terkait Cara Penggunaan MeteredDose Inhaler dengan Spacer yang Mengandung Kombinasi Beta-2 Agonis dan Kortikosteroid oleh Apoteker di Apotek Wilayah Surabaya Timur, Jurnal Ilmiah Manuntung (JIM) Sains Farmasi dan Kesehatan, Akademi Farmasi Samarinda, 4(1):15-27.

23. Lorensia, A., Setiawan, B., Maranatha, D., Yudiarso, A., 2017, Effectiveness of Education Based InformationMotivation-Behavioral Skill (IMB) Model of Improving Knowledge, Motivation, and Performance Demonstration Metered-Dose Inhaler (MDI) to Community Pharmacists in Surabaya, International Journal of Pharmaceutical and Clinical Research (IJPCR), 9(7):485-95.

24. Basheti, I.A., Natsheh, A.I., Ammari, W.G., Khater, S., Qunaibi, E.A., Bosnic, S.Z., 2015, Education on Correct Inhaler Technique in Pharmacy Schools: Barriers and Needs, Trop $J$ Pharm Res, 14(4):715-22.

25. Peraturan Menteri Kesehatan RI Nomor 73 tahun 2016 tentang Standar Pelayanan Kefarmasian di Apotek.

26. Salina, L., Ruffinengo, C., Garrino, L., 2012, Effectiveness of an educational video as an instrument to refresh and reinforce the learning of a nursing technique: a randomized controlled trial, Perspect Med Educ, 1(2):67-75.

27. Hurtubise, L., Martin, B., Gilliland, A., Mahan, J., 2013, To play or not to play: leveraging video in medical education, J Grad Med Educ, 5(1):1318.

28. Peraturan Menteri Kesehatan RI Nomor 1023 tahun 2008 tentang Pedoman Pengendalian Penyakit Asma.

29. Sims, M.W., 2011, Aerosol Therapy for Obstructive Lung Diseases, Chest, 140(3):781-8.

30. Berge, V.M., Hacken, N.H., Wiel, D.E., Postma, D.S., 2013, Treatment of the bronchial tree from beginning to end: targeting small airway inflammation in asthma, Allergy, 68(1):16-26.

31. Sobande, P.O., Kercsmar, C.M., 2008, Inhaled Corticosteroids in Asthma Management, Respiratory Care, 53(5):625-634.

32. Price, D., Bosnic-Anticevich, S., Briggs, A., Chrystyn, H., et al., 2013, Inhaler competence in asthma: common errors, barriers to use and recommended solutions, Respiratory medicine, 107(1):37-46.

33. Lee, S.M., Chang, Y.S., Kim, C.W., Kwon, Y.E., 2011. Skills in Handling Turbuhaler, Diskus, and Pressurized Metered-Dose Inhaler in Korean Asthmatic Patient, Allergy Asthma Immunology, $\quad 3(1): \quad 46-42$. 
About Current Archives Focus and Scope Publication Ethics Sitemap

Search

Home / Archives / Vol 6 No 2 (2020): Jurnal Ilmiah Manuntung

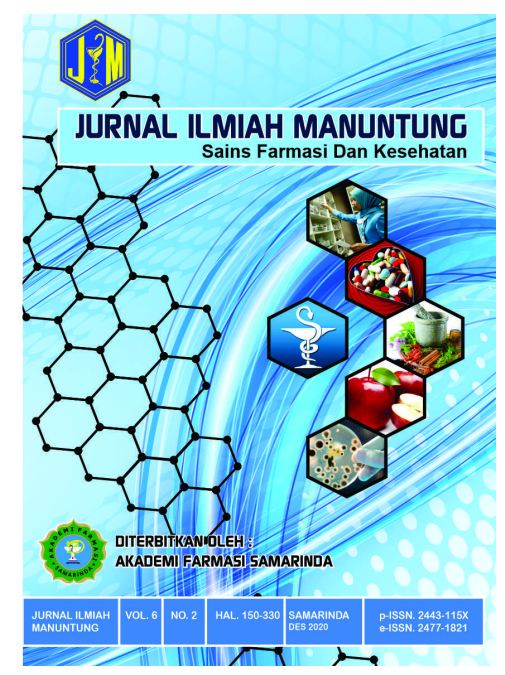

Jurnal Ilmiah Manuntung adalah Jurnal tentang Sains Farmasi dan Kesehatan yang diterbitkan oleh Akademi Farmasi Samarinda yang meliputi kajian Ilmu Farmasi, Kedokteran, Kimia Organik Sintetis, Kimia Organik Bahan Alam, Biokimia, Kimia Analisis, Kimia Fisis, Biologi, Mikrobiologi, Kultur Jaringan, Botani dan hewan yang terkait dengan produk farmasi, keperawatan, Kebidanan, Analis Kesehatan, Gizi dan Kesehatan Masyarakat.

Published: 2020-12-30

\section{Artikel}

\section{EFEKTIVITAS EDUKASI VIDEO UNTUK KELENGKAPAN PENJELASAN CARA PENGGUNAAN INHALER} OLEH MAHASISWA APOTEKER

Amelia Lorensia, Rifaatul Laila Mahmudah, Ema Arifatul Masruroh, Navaul Setiya Ningrum

150-162 
因 PDF

OPTIMASI VARIASI KONSENTRASI LIPID TERHADAP KARAKTERISTIK FISIK SOLID LIPID NANOPARTICLE (SLN) GLIBENKLAMID

Nurul Arfiyanti Yusuf, Rahmad Aksa, Fisa Juniawan Cahyono

163-171

因 PDF

PENGUKURAN KINERJA INSTALASI FARMASI RUMAH SAKIT DAERAH LIUN KENDAGE TAHUNA BERDASARKAN PERSPEKTIF CUSTOMER DAN LEARNING AND GROWTH

Gayatri Citraningtyas, Deby Afriani Mpila, Mariana Gagola

172-182

$\triangle \mathrm{PDF}$

AKTIVITAS ANTIKOLESTEROL EKSTRAK ETANOL BUAH KIWI HIJAU (Actinidia deliciosa) Novena Yety Lindawati, Desi Widya Ningsih

183-191

因PDF

PENETAPAN KADAR FLAVONOID TOTAL JUS BUAH DELIMA (Punica granatum L.) YANG BERPOTENSI SEBAGAI HEPATOPROTEKTOR DENGAN METODE SPEKTOFOTOMETRI UV-VIS

Suharyanto Suharyanto, Anisa Dinda Ramadhani

192-198

因 PDF

ANALISIS KINERJA PELAYANAN APOTEK DAN KINERJA KEUANGAN PADA APOTEK PROGRAM RUJUK BALIK (PRB)-KRONIS BPJS DAN APOTEK TIDAK BEKERJA SAMA BPJS DI KOTA BOGOR, JAWABARAT

M. Kenli Kendi Tampoliu, MGS. Aritonang, Yusi Anggriani

199-208

目PDF

UJI DAYA HAMBAT EKSTRAK ETANOL DAUN MAHKOTA DEWA (Phaleria macrocarpa Boerl.,) TERHADAP Klebsiella pneumonia.

Putri Afiana Solicah, Aulia Nur Rahmawati

209-214

$\Delta \mathrm{PDF}$ 
EFEKTIVITAS GEL EKSTRAK AIR UMBI BAWANG PUTIH TERHADAP PENYEMBUHAN LUKA BAKAR DAN LUKA SAYAT

Irene Puspa Dewi, Verawaty Verawaty, Tuty Taslim

215-222

因 PDF

FORMULASI DAN EVALUASI SEDIAAN MASKER SHEET EKSTRAK ETANOL DAUN SIRIH MERAH (Piper crocatum Ruiz \& Pav)

Verawaty Verawaty, Novita Sulimar, Irene Puspa Dewi

223-230

因 PDF

UJI AKTIVITAS ANTIOKSIDAN DAN TABIR SURYA KOMBINASI EKSTRAK KULIT BUAH PISANG KEPOK (Musa Paradisiaca Linn) DAN EKSTRAK KULIT BUAH ALPUKAT (Persea Americana Mill)

Wimpy Wimpy, Tri Harningsih, Whella Thalitha Larassati

231-239

因 PDF

SKRINING ANTIOKSIDAN DAN ANTIKANKER EKSTRAK ETANOL DAUN KARAMUNTING (RHONOMYRTUS TOMENTOSA L.) SEBAGAI OBAT ALTERNATIF

Marwati Marwati, Mirnawati Salampe, Asril Burhan, Megawati Megawati, Khairuddin Khairuddin, A.Adi Al Ma'aridj Naneng, Nova Oktaviani

240-245

$\triangle \mathrm{PDF}$

Antibakteri UJI AKTIVITAS ANTIBAKTERI EKSTRAK ETANOL DAUN MEKAI (Pycnarrhena cauliflora DIELS.) TERHADAP Staphylococcus aureus

Yayuk Bulam Sarifati, Sjarif Ismail, Khemasili Kosala

246-251

因DF

PENGARUH PROSES MASERASI DENGAN VARIASI KONSENTRASI PELARUT ETANOL TERHADAP KANDUNGAN SENYAWA EKSTRAK DAUN PEPAYA (Carica papaya L.) DAN DAUN UBI JALAR UNGU (Ipomoea batatas L. Lam)

Nurlaili Ekawati, Herman Irawan, Djadjat Tisnadjaja, Sevty Syera

252-264

因 PDF 
GAMBARAN PENGGUNAAN ANTIBIOTIK PADA PASIEN ULKUS DIABETIKUM DI INSTALASI RAWAT JALAN PENYAKIT DALAM RSUD ULIN BANJARMASIN PERIODE JULI - DESEMBER 2018

Saftia Aryzki, Merry Alicia, Siti Rahmah

265-272

因 PDF

UJI STABILITAS DAN IRITASI FORMULA KRIM ANTI NYERI EKSTRAK ETANOL DAUN KELOR (Moringa oleifera)

Amriani Sapra, Suwahyuni Mus, Rifka Malluka, Dwirandy Dwirandy

273-279

因 PDF

PEMBUATAN STRIP TEST DAN IDENTIFIKASI FENILBUTAZON PADA JAMU PEGAL LINU

Henny Nurhasnawati, Triswanto Sentat, Adi Prasetiyo

280-285

因 PDF

UJI POTENSI EKSTRAK DAUN BENALU BATU (BEGONIA SP) TERHADAP KADAR GLUKOSA DALAM DARAH DAN GAMBARAN HISTOPATOLOGI PANKREAS TIKUS PUTIH JANTAN (RATTUS NORVEGICUS)

Joni Tandi, Dela Erni Paerunan, Nurifa Nurifa, Yunlis Silintowe Kenta, Sri Mulyani

286-298

园 $\mathrm{PDF}$

UJI AKTIVITAS EKSTRAK ETANOL DAUN EKOR NAGA (Rhaphidophora pinnata (L.f.) Schott.) SEBAGAI ANTIHIPERURISEMIA TERHADAP MENCIT PUTIH JANTAN

Bella Pascila, Fathnur Sani K, Revis Asra, Agung Giri Samudra

299-305

因DF

EFEKTIVITAS DAN KEAMANAN TERAPI NATRIUM DIKLOFENAK DAN PIROKSIKAM PADA PASIEN OSTEOARTHRITIS DI PUSKESMAS KOTA SURABAYA

Selly Septi Fandinata, Anita Purnamayanti, Primanitha Ria Utami

306-311

图 PDF

PENGUJIAN EFEKTIFITAS FORMULA GEL EKSTRAK DAUN BELUNTAS (Pluchea indica (L.) Less) DENGAN VARIASI KONSENTRASI GELLING AGENT SEBAGAI KANDIDAT SEDIAAN ANTI JERAWAT 
Andi Ulfah Magefirah Rasyid, Zahira Amody

312-322

因 PDF

AKTIFITAS ANTIBAKTERI DARI SEDIAAN FOOTSANITIZER SPRAY KOMBINASI EKSTRAK BIJI KOPI (Coffea) DAN RIMPANG JAHE (Zingiber officinale)

Wilda Amananti, Dairoh Dairoh

323-330

PDF

\section{Akreditasi}

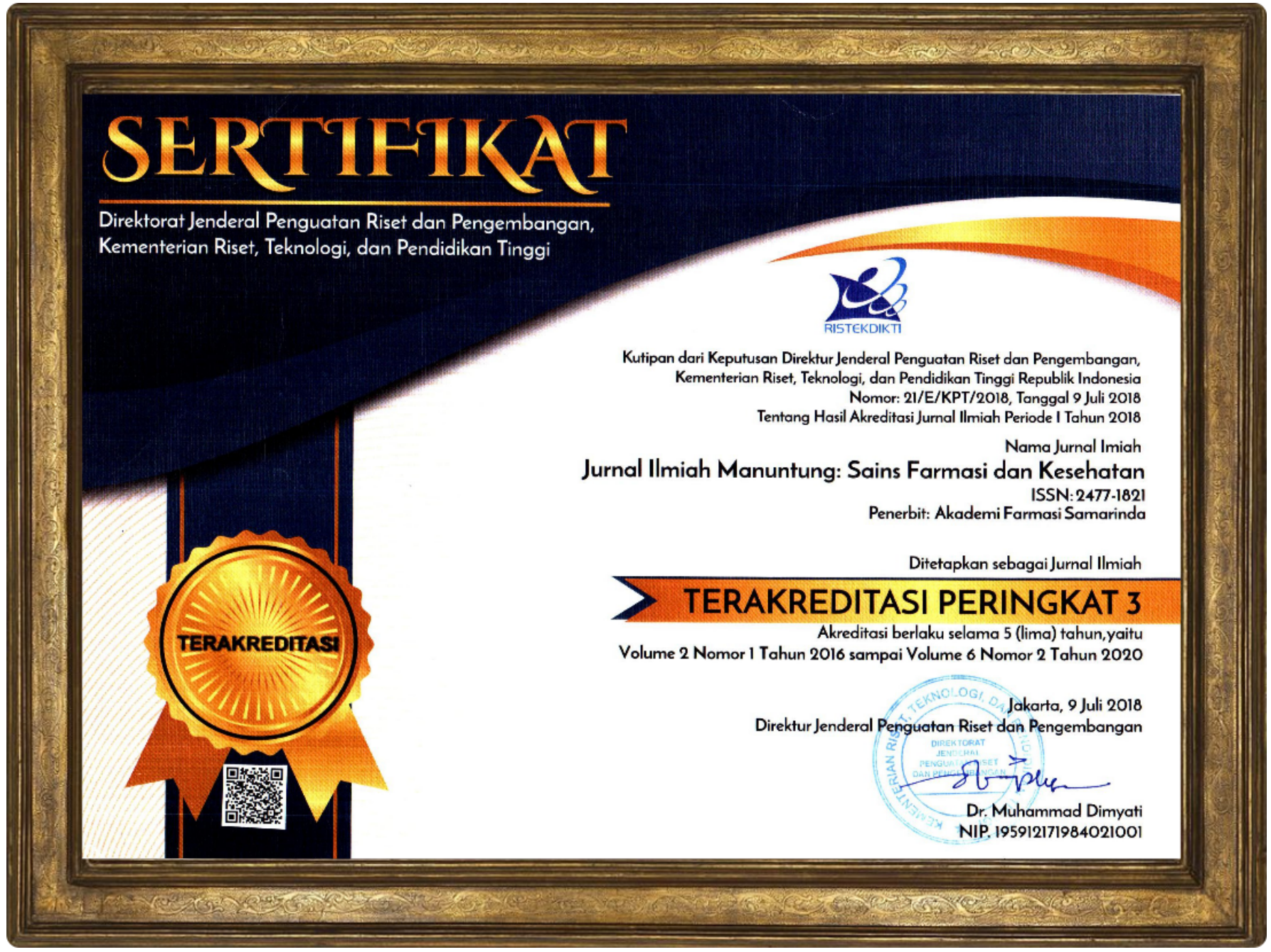

\section{Policies}




\section{Editorial Team}

\section{Plagiarism Policy}

Open Acces Policy

\section{Digital Archiving}

\section{Copyright Notice}

\section{Peer Review Process}

\section{Submit Guidelines}

Template_Journal

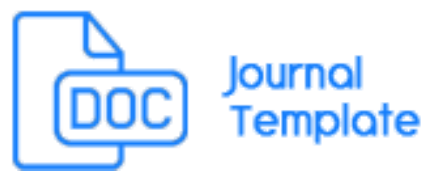

\section{VISITORS}

FFlag Counter

Wweb analytics View My Stats

\section{INDEXED}
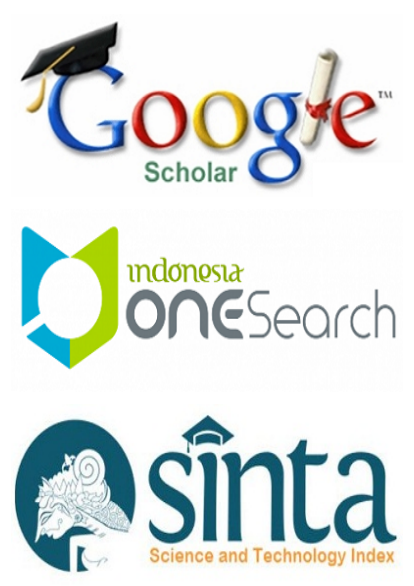


\section{JURNAL ILMIAH MANUNTUNG}

About Current Archives Focus and Scope Publication Ethics Sitemap

Search

Home / Editorial Team

\section{Director}

- Supomo, M.Si., Apt., Akademi Farmasi Samarinda, Indonesia

\section{Chief Editor}

- Yulia Sukawaty, M.Sc., Apt., Akademi Farmasi Samarinda, Indonesia

\section{Editors}

- Reksi Sundu, M.Sc., Apt., Akademi Farmasi Samarinda, Indonesia

- Henny Nurhasnawati, S.Si., M.Si., Akademi Farmasi Samarinda, Indonesia

- Risa Supriningrum, S.Si., M.M., Akademi Farmasi Samarinda, Indonesia

- Eka Siswanto, M.Sc., Apt., Akademi Farmasi Samarinda, Indonesia

- Hayatus Sa'adah, M.Sc., Apt., Akademi Farmasi Samarinda, Indonesia

- Husnul Warnida, M.Si., Apt., Akademi Farmasi Samarinda, Indonesia

\section{Administration}

- Irwansyah, Akademi Farmasi Samarinda, Indonesia 


\section{Akreditasi}

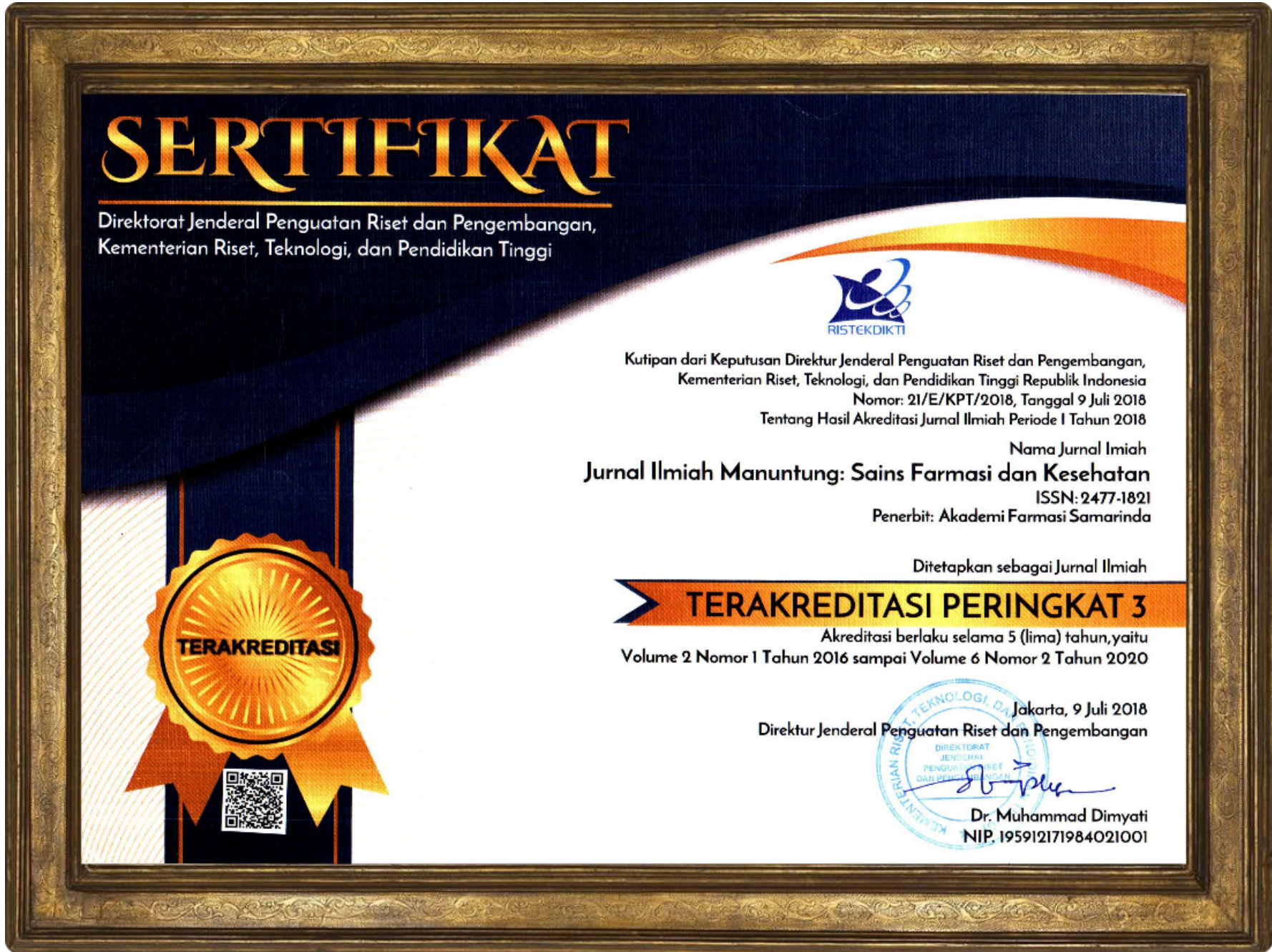

\section{Policies}

\section{Author Charge}

\section{Editorial Team}

\section{Plagiarism Policy}

Open Acces Policy

\section{Digital Archiving}

\section{Copyright Notice}

\section{Peer Review Process}

\section{Submit Guidelines}


Template_Journal

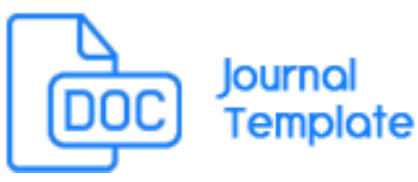

\section{VISITORS}

AFlag Counter

Aweb analytics View My Stats

\section{INDEXED}
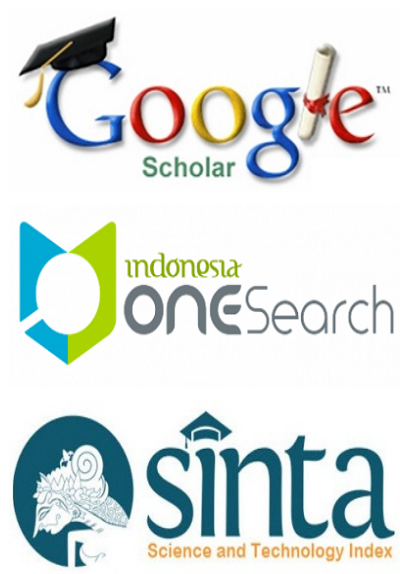

\section{PKPINDEX}

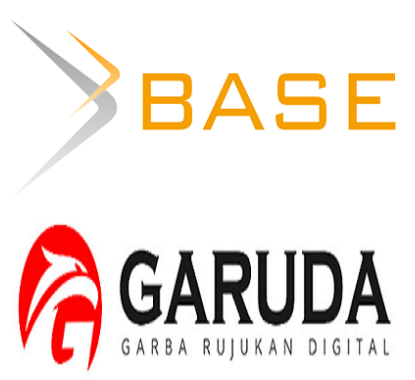

ISSN

p-ISSN. 2443-115X 
e-ISSN. 2477-1821

\section{LPPM Akademi Farmasi Samarinda}

Jl. Brig. Jend. Abdul Wahab Sjahranie No. 226, Air Hitam

Samarinda, Kalimantan Timur, Indonesia

Telp : (0541) 7777363

Email : ejournal.akfarsam@gmail.com

\section{(c) (†) ()}

This work is licensed under a Creative Commons Attribution-ShareAlike 4.0 International License.

powered by OJS | Open Journal Systems

PKP | PUBLIC KNOWLEDGE PROJECT 